\title{
Estimation of genetic parameters for subclinical mastitis using a threshold model in first parity dairy cows under pasture-based systems of Los Ríos Region in Chile
}

\author{
Hector Uribe ${ }^{\mathrm{a} *}$, Felipe Lembeye ${ }^{\mathrm{b}}$, Humberto González ${ }^{\mathrm{a}}$
}

\begin{abstract}
Somatic cell count (SCC) is an indirect measurement to estimate mammary gland health status. This trait provides information regarding the severity of the mammary tissue inflammation in each quarter. Milk samples coming from the farm milk storage vat containing 100,000 to 200,000 cell/mL are considered suspicious, while SCC over 200,000 cell/mL is an indication of subclinical mastitis. Chilean dairy processors penalise farmers monetarily when their bulk tank samples reach levels of 300,000 cell/ $\mathrm{mL}$ SCC. The objective of this study was to quantify the additive genetic component of the liability of cows to reach the 300,000 cell/mL threshold. A data set containing the highest SCC test-day record of 10,528 first lactation cows from 15 commercial dairy farms of Los Ríos Region in southern Chile was analysed. The unknown continuous underlying susceptibility of each cow to reach the 300,000 SCC threshold was modelled as a function of a contemporary group formed by the herd, year, and calving season, the regression coefficient of the unknown underlying susceptibility value of a cow on her daily milk yield (MY) and the additive animal genetic effect. Bayesian inference and Gibbs sampling were used to estimate additive and residual variances. The average daily MY and SCC were $17.84 \pm 5.25 \mathrm{~kg}$ and $125,327 \pm 236,297 \mathrm{cell} / \mathrm{mL}$, respectively. The estimated heritability varied from 0.03 to 0.22 and the average was $0.10 \pm 0.03$. It is concluded that the genetic variability for the susceptibility to reach the $300,000 \mathrm{SCC}$ threshold could be exploited to improve resistance to subclinical mastitis.

Key words: milk, subclinical mastitis, threshold model, heritability.
\end{abstract}

\section{INTRODUCTION}

Mammary gland health status is a crucial issue in dairy cows to yield a milk volume and quality that is needed to keep an economically feasible dairy operation. Mastitis in dairy cattle is the most prominent and economically significant disease and a major cause of economic losses for dairy farmers. These losses are a direct result of reduced milk yield (MY), death, premature culling, veterinary costs, lost milk due to antibiotic use, and low milk quality (Bravo 2009, Miglior et al 2017, Ruegg and Pantoja 2013, Kirsanova et al 2019). However, subclinical mastitis is the most prevalent type of intramammary infection. This alteration cannot be detected by visual observation of the udder or milk because both appear normal, therefore, it remains a hidden disease. Cows with subclinical mastitis are usually not detected nor treated, and consequently, their reduction in MY and milk quality causes the greatest economic loss on dairy farms (Kumari et al 2018). An increase in somatic cell count (SCC) is observed as the health of the mammary gland decreases, therefore, the prevalence of subclinical mastitis is reflected in the herd SCC.

Somatic cell count is a well-known alternative procedure used to estimate mammary gland health condition that

Received: 13.04.2021.

Accepted: 10.08.2021.

a'Departamento de Producción Animal, Facultad de Ciencias Agronómicas, Universidad de Chile, Santiago, Chile.

boprole S.A., Departamento Agropecuario, Gerencia de Materias Primas Lácteas, Santiago, Chile.

*Corresponding author: hector.a.uribe@gmail.com provides information regarding the severity of the mammary tissue inflammation in each quarter, and milk samples can also come from the farm milk storage tank (Bravo 2009, Kirsanova et al 2019, Ruegg and Pantoja 2013). According to the International Dairy Federation (1997), Sharma et al (2011) and Ruegg and Pantoja (2013) milk samples containing 100,000 to 200,000 cell $/ \mathrm{mL}$ are considered suspicious, while SCC over 200,000 cell $/ \mathrm{mL}$ of milk is an indication of subclinical mastitis presence. Chilean legislation does not explicit an SCC legal limit, however, in the southern regions of the country and, due to their low-quality milk association, domestic dairy processors economically penalise dairy farmers when their milk bulk tanks SCC reach 300,000 cell $/ \mathrm{mL}$.

Somatic cell count was introduced into many milk recording programs in North America and Europe in the late 1970s, raising renewed interest in selection for mastitis resistance (Miglior et al 2017). Several milk-producing countries have in place programs to reduce mastitis incidence and one of the actions is the genetic selection to reduce SCC by including this trait in their breeding programs (National Mastitis Council 2013). Except for the Scandinavian countries, direct selection for clinical mastitis has not been accomplished. In countries without regulated systems for dairy cattle health recording, obtaining sufficient records of health events for genetic evaluation is an issue that has not been properly addressed (Miglior et al 2017). At the farm level, individual cases of diseases are not routinely recorded and, therefore, data is not readily available. Nevertheless, there is evidence that mastitis could be reduced by selecting against affected cows (Miglior et al 2017), despite its low heritability (López-Villalobos et al 2014, Lembeye et al 2016). 
According to the International Dairy Federation (1997), cows with SCC over 200,000 cell $/ \mathrm{mL}$ can be regarded as having subclinical mastitis, which allows using milk recording data to indirectly record subclinical mastitis incidence. Subclinical mastitis and many diseases may be recorded as present or absent, creating binary data and linear statistical models assuming normal distribution are not well suited for analyses of this type of data (Uribe et al 1995, Kadarmideen et al 2000). Non-linear threshold models have been proven to be theoretically better to analyse binary data and estimate genetic parameters (Gianola and Foullley 1983, Harville and Mee 1984).

The objective of this study was to estimate the prevalence and genetic variability of subclinical mastitis as an indirect trait based on surpassing an arbitrary SCC threshold, using a non-linear threshold model in first lactation dairy cows of Los Ríos Region, Chile.

\section{MATERIAL AND METHODS}

A data set containing 97,683 monthly test-day records of 10,528 first parity cows was used in this study, and from the pedigree files only 2,350 ancestors without records were included. Out of the 10,528 phenotyped animals, 7,377 had both parents known (71\%), 2,109 had one parent missing (20\%) and 1,042 had both parents missing (9\%). Out of the 2,350 unphenotyped animals, $434 \mathrm{had}$ both parents known (19\%), 276 had one parent missing (12\%), and 1,640 had both parents missing (69\%). The above implies that the number of animals with missing parents is important.

Data gathered contained information from 1996 to 2019 in 15 commercial dairy herds of Los Ríos Region in southern Chile. Cow's breed composition was predominantly Holstein Friesian although other dairy breeds and crosses are also part of the southern Chile dairy population, unfortunately, the exact breed identification was not available in the data set.

Regarding the age of calving, only heifers calving for the first time from 20.5 to 40 months of age were included in this study. Milk yield test-day records below five and above $35 \mathrm{~kg}$ of MY and below six and above 305 days of lactation were deleted from the data set. Within each cow, its test-day records were sorted by SCC and only the largest record was left in the data set, hence the final data set had a single record on any of the 10,528 cows included in the study. Although subclinical mastitis results when SCC is greater than $200,000 \mathrm{cell} / \mathrm{mL}$, most Chilean raw milk payment schemes penalise dairy farmers when bulk tank SCC reaches 300,000 cell $/ \mathrm{mL}$. In this study, the cows with records above such level were assumed to have subclinical mastitis.

Records of the presence or absence of subclinical mastitis, as defined in this study, generate discrete data that follows a binomial distribution. Therefore, estimation of genetic parameters by the usual method for mixed linear models, which are traditionally used for continuous traits, is not appropriate. However, it can be argued that subclinical mastitis observations lie on one of two ordered categories (surpassing or not $300,000 \mathrm{SCC}$ ), and susceptibility of animals to reach this limit follows an underlying continuous normal distribution that is not observed. Only those animals which exceed some threshold of susceptibility show more than 300,000 SCC. The underlying continuous susceptibility is assumed to be affected by both genetic and environmental factors and each animal has a non-observable, hypothetical random variable similar to a measurable phenotype in a continuous trait.

In such a model, the classification of an animal in one category or another depends on a susceptibility threshold, which is also unknown. In a usual mixed linear model, the outcome vector contains the real observations of a particular continuous trait, in this case, this vector represents the unobserved values on the underlying normal continuous scale of susceptibility to subclinical mastitis. This outcome vector is not observed directly, all that we observe is the presence or absence of subclinical mastitis. Gianola and Foullley (1983), and Harville and Mee (1984) proposed a nonlinear set of equations that are solved iteratively for the values of the threshold and effects included in the model (fixed and random), for the analysis of categorical data based on a threshold model.

The univariate animal threshold model, used to analyse the underlying susceptibility to subclinical mastitis and estimate variance components, was:

$$
\mathrm{y}_{\mathrm{ijk}}=\mu+\operatorname{HYS}_{\mathrm{i}}+\mathrm{b}_{\mathrm{ijk}}(\mathrm{M})+\mathrm{a}_{\mathrm{j}}+\mathrm{e}_{\mathrm{ijk}}
$$

Where: $y_{i j k}=$ is the unknown continuous underlying susceptibility value of the observation $\mathrm{k}$ made by cow $\mathrm{j}$ in the contemporary group i. $\mu=$ is the population mean. $\mathrm{HYS}_{\mathrm{i}}=$ is the fixed effect of the contemporary group made by cows controlled in the same herd, year, and season. $b_{i j k}=i s$ the regression coefficient of the unknown underlying susceptibility value of cow $\mathrm{j}$ on her test-day milk yield. $\mathrm{M}=$ is the milk yield of the cow $\mathrm{j} \cdot \mathrm{a}_{\mathrm{j}}=$ is the random animal additive genetic effect which follows a normal distribution with mean equal cero and a covariance structure equal to the additive genetic relationship matrix multiplied by de genetic variance $\left(\sigma_{\mathrm{a}}^{2}\right) \sim \mathrm{N}\left(0, A \sigma_{\mathrm{a}}^{2}\right) . \mathrm{e}_{\mathrm{ijk}}=$ is the residual error $\sim \mathrm{N}\left(0, \mathrm{I} \sigma_{\mathrm{e}}^{2}\right)$.

In the given contemporary group ( $\left.\mathrm{HYS}_{\mathrm{i}}\right)$ all cows tested in the same herd (15), year (24), and test-day season (3) were included. The test-day season had three levels, cows tested from March to June, July to October (spring), and November to February were levels one, two, and three, respectively.

To solve the threshold model and estimate variance components the RENUMF90 and THRGIBBSF90 software were used ${ }^{1}$. The THRGIBBSF90 software handles threshold

Misztal I, Tsuruta S, Lourenco DAL, Masuda Y, Aguilar I. 2018. 
Table 1. Number of cows (N), mean, standard deviation (SD), and minimum (Min) and maximum (Max) values for milk yield (MY) and somatic cell count (SCC) by subclinical mastitis status (SMS).

\begin{tabular}{lcccccc}
\hline SMS & $\mathrm{N}$ & Trait & Mean & $\mathrm{SD}$ & Min & Max \\
\hline Up to 300,000 cell/ml. & \multirow{2}{*}{6,985} & $\mathrm{MY}^{1}$ & 17.03 & 5.42 & 5.00 & 34.80 \\
& & $\mathrm{SCC}^{2}$ & 130,409 & 73.579 & 18,000 & 300,000 \\
Above 300,000 cell/ml. & \multirow{2}{*}{3,543} & $\mathrm{MY}^{1}$ & 16.30 & 5.45 & 5.00 & 34.74 \\
All cows & & $\mathrm{SCC}^{2}$ & 871,832 & 634,497 & 301,000 & $2,995,000$ \\
& \multirow{2}{*}{10,528} & $\mathrm{MY}^{1}$ & 16.78 & 5.44 & 5.00 & 34.80 \\
& & $\mathrm{SCC}^{2}$ & 379,922 & 511,663 & 18,000 & $2,995,000$ \\
\hline
\end{tabular}

${ }^{1}=\mathrm{kg} / \mathrm{day}$

${ }^{2}=\mathrm{cell} / \mathrm{mL}$

models using Bayesian inference and Gibbs sampling (Gianola and Sorensen 2002, Misztal 2008). In Bayesian statistics, the posterior distribution of a random variable is given by a prior density function which is updated by the information contained in the data, given the other parameters of a particular model. The joint posterior distribution contains all information needed to make inference about all parameters in the model, however, analytical integration of the joint posterior distribution, to obtain the marginal posterior distribution of the parameters of interest (covariances) is extremely difficult to perform in practice, therefore, approximations like the Gibbs sampler have been advocated to fully exploit Bayesian inference (Casella and George 1992). Gibbs sampling is an iterative process to draw the joint posterior distribution out of the samples generated as random numbers based on information available at a specific point. In a single iterate, the Gibbs sampler solves the mixed model equations with the current variance components and adds a small random number (noise) to each solution, variance components are then estimated. This process is repeated many times and, after a burn-in period, the average of samples (posterior marginal mean) provides estimators of covariance components. The corresponding mean is the Bayesian estimated parameter and, the standard deviation of samples (SD) corresponds to the standard error of the estimated variance component in a frequentist approach.

In this study, a single chain length of 200,000 was generated and the first 30,000 iterates of the chain were discarded as the burn-in period. The remaining 170,000 iterates were used for estimation of means of the marginal posterior distribution of the variance components as described by Sorensen et al (1995). Heritability $\left(\mathrm{h}^{2}\right)$ of the unknown continuous underlying susceptibility to subclinical mastitis was estimated as $h^{2}=\sigma_{a}^{2} / \sigma_{a}^{2}+\sigma_{e}^{2}$, where: $\sigma_{a}^{2}$ is the additive genetic variance and $\sigma_{\mathrm{e}}^{2}$ is the residual variance.

Manual for BLUPF90 family programs. University of Georgia. Available at: http://nce.ads.uga.edu/wiki/doku.php?id=documentation

\section{RESULTS AND DISCUSSION}

The average daily MY and SCC in this sample of 10,528 first lactation cows were $16.78 \pm 5.44 \mathrm{~kg}$ and $379,922 \pm 511,662$ cell $/ \mathrm{mL}$, respectively. Minimum and maximum SCC were 18,000 and 2,995,000 cell/mL, respectively. These averages included only the highest SCC record of each cow, when all test-day records of each cow were considered $(97,256)$ the corresponding averages were $17.84 \pm 5.25 \mathrm{~kg}$ of milk and $125,327 \pm 236,297$ cell $/ \mathrm{mL}$, respectively. Assuming a 305 days lactation the estimated lactation MY is $5,441 \mathrm{~kg}$. This value is lower than the average indicated by Montaldo et al (2015) who studied G×E interaction of proven sires between the US and Chile, analysed 243,134 Chilean cow lactations gathered from 1997 to 2008 and reported that the average lactation MY across lactation was $8,082 \mathrm{~kg}$. This large difference can be explained because the lactation records used by Montaldo et al (2015) included all lactations and were adjusted to 305 days mature equivalent MY. Also, a MY higher $(7,408 \mathrm{~kg})$ than that reported in this research was that indicated by Pinedo and Meléndez (2010) for 305 days mature equivalent MY in Chilean Holstein cows. The literature reviewed in this study does not report the average test-day milk yield for Chilean cows.

The average SCC, calculated using all available records $(97,256)$ of the 10,528 cows, was $125,327 \pm 236,297$ cell/ $\mathrm{mL}$ which is lower than the SCC reported by Pinedo and Meléndez (2010) who included lactations from 187 herds recorded from 1997 to 2007 and indicated that the average SCC decreased from 489,000 to 309,000 cell $/ \mathrm{mL}$. Similar to the present study, Werner (2014) reported an average SCC of $151,131 \mathrm{cell} / \mathrm{mL}$ by analysing 640,249 Chilean lactations in farms located in southern Chile (Malleco to Chiloé).

Table 1 shows the number of cows, mean, standard deviation, and minimum and maximum values for milk yield and SCC according to the subclinical mastitis status of the cows. Sixty-six per cent of the cows $(6,985)$ did not reach the threshold of 300,000 cell $/ \mathrm{mL}$ while the remaining $34 \%$ (3,543 cows) were classified as having subclinical mastitis. As expected, cows that reached the 300,000 cell/ 
mL SCC threshold yielded less milk $(16.30 \pm 5.45 \mathrm{~kg})$ when compared to healthy cows $(17.02 \pm 5.42 \mathrm{~kg})$.

Considering the highest SCC record of each cow used in this study $(10,528$ cows, table 1$)$, the average SCC was 379,921 cell $/ \mathrm{mL}$ which is greater than the average SCC of 151,131 cell/mL reported by Werner (2014). A possible explanation is that in this study, among all testday records available for each cow only the greatest one was used in computing the average. Pineda and Meléndez (2010) reported an average SCC of 309,000 cell/mL in 2007, and according to the International Dairy Federation (1997) guidelines the average Chilean Holstein cow had subclinical mastitis, fortunately, this prevalence has decreased according to Werner (2014) who indicated an average SCC of $151,131 \mathrm{cell} / \mathrm{mL}$.

Somatic cell count is an accepted indirect method for the diagnostic of subclinical mastitis (Bravo 2009, Kirsanova et al 2019, Ruegg and Pantoja 2013), and albeit the International Dairy Federation (1997) indicated that an SCC above 200,000 cell $/ \mathrm{mL}$ is an indication of subclinical mastitis presence, in this study the SCC threshold was arbitrarily fixed at 300,000 cell/mL because this is the limit accepted by the Chilean dairy processors to start monetarily penalising raw milk. Other definitions of subclinical mastitis, based on the number of consecutive days reaching a given SCC threshold, have also been explored (Bobbo et al 2018). According to the definition of subclinical mastitis chosen in this study, thirty-four per cent of the cows had the disease and their average SCC was 871,832 cell $/ \mathrm{mL}$, while cows that did not reach the SCC threshold had an SCC average of 130,409 cell/mL (table 1). Bravo (2009) used data from 1,286 black and white dairy cattle of a research farm in Purranque, south of Chile, to estimate a subclinical mastitis prevalence of $38.9 \%$ which is similar to that reported in this study. Bobbo et al (2018) analysed 574,174 test-day records of 66,784 first parity Holstein cows (20 to 40 months of age) from 404 herds in northeast Italy and reported that subclinical mastitis infected cows, defined as those that reached an SCC of 400,000 cell $/ \mathrm{mL}$, was $47 \%$.

Table 2 shows the means and their standard errors of 170,000 Gibbs samples of the marginal posterior distribution for genetic and residual variances. Figure 1 shows the sample values pattern of $h^{2}$ after the 30,000 samples burn-in period, the steadiness of the pattern indicates that convergence has been met. Similar steady patterns were also obtained for genetic and residual variances. All standard deviations were very low as compared to their

Table 2. Estimated mean, standard error (SE), minimum (Min) and maximum (Max) values of the genetic $\left(\sigma_{\mathrm{a}}^{2}\right)$ and residual $\left(\sigma_{\mathrm{e}}^{2}\right)$ variance, and heritability $\left(\mathrm{h}^{2}\right)$.

\begin{tabular}{ccccc}
\hline & Mean $^{1}$ & SE & Min & Max \\
\hline$\sigma_{\mathrm{a}}^{2}$ & 0.12 & 0.04 & 0.03 & 0.29 \\
$\sigma_{\mathrm{e}}^{2}$ & 1.04 & 0.02 & 0.96 & 1.13 \\
$\mathrm{~h}^{2}$ & 0.10 & 0.03 & 0.03 & 0.22 \\
\hline
\end{tabular}

${ }^{1}=170,000$ Gibbs samples.

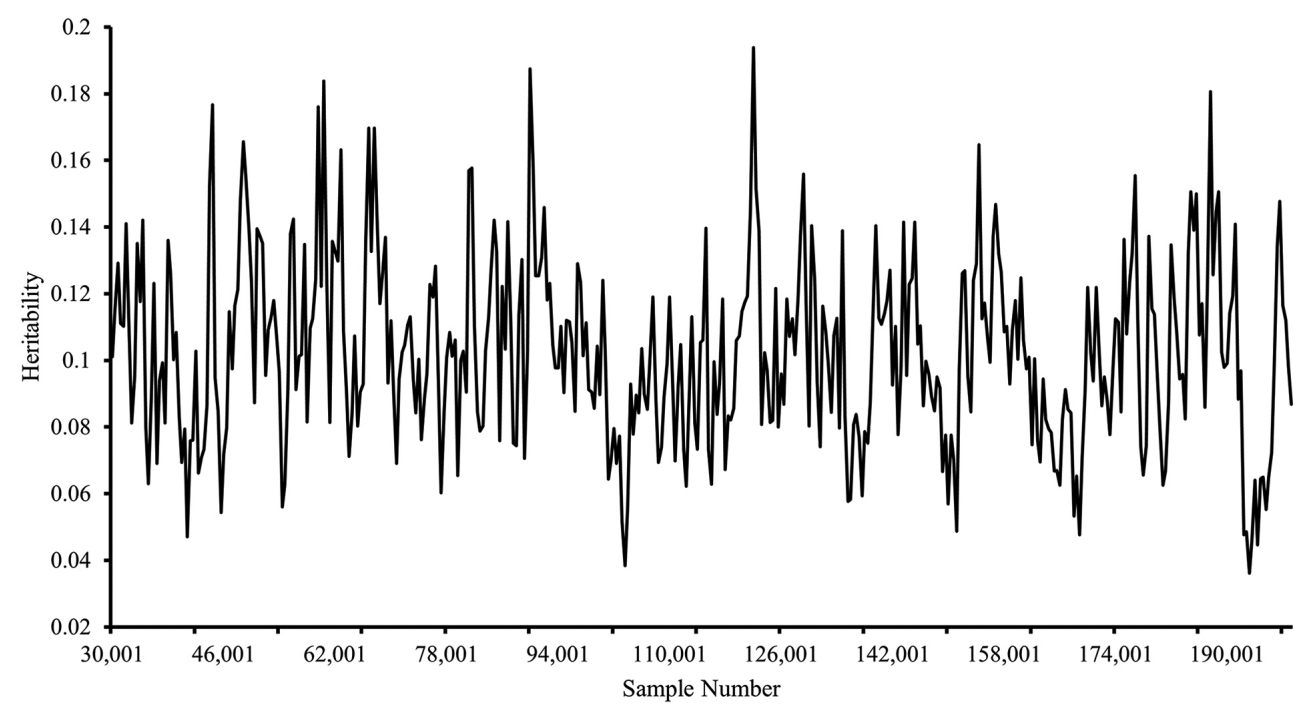

Figure 1. Gibbs samples pattern for heritability estimates after the burn-in period. 
corresponding means which indicates that the estimated parameters are different from zero hence not meaningless.

Heritability estimated for subclinical mastitis in this study was $0.10 \pm 0.03$ (table 2 ). Using a linear repeatability animal model Kirsanova et al (2019) estimated $\mathrm{h}^{2}$ in Norwegian Red cows in lactation 1 to 3 , for several subclinical mastitis traits as defined according to SCC thresholds from 50,000 to 400,000 cell $/ \mathrm{mL}$, their estimate for the 300,000 cell $/ \mathrm{mL}$ threshold was $0.06 \pm 0.002$ which is inferior to that reported in this study. In the study of Kirsanova et al (2019), smaller SCC thresholds had higher $\mathrm{h}^{2}$ estimates, for instance, the $150,000 \mathrm{cell} / \mathrm{mL}$ threshold had $\mathrm{h}^{2}$ equal to $0.10 \pm 0.002$ which is identical to the $\mathrm{h}^{2}$ estimated here for the 300,000 cell $/ \mathrm{mL}$ threshold. Uribe et al (1995), estimating genetic parameters for common health disorders of Canadian Holstein cows and using a non-relationship sire threshold model, reported $\mathrm{h}^{2}$ for clinical mastitis of 0.15. Kadarmideen et al (2000) estimated the $\mathrm{h}^{2}$ of several clinical diseases in UK dairy cows and their estimation for clinical mastitis using a non-relationship sire threshold model was $0.126 \pm 0.033$. On the other hand, Bobbo et al (2018) estimated $\mathrm{h}^{2}$ of $0.06 \pm 0.01$ for Italian Holstein cows reaching a SCC threshold of 400,000 cell/ $\mathrm{mL}$, this is lower than the $\mathrm{h}^{2}$ estimated in this study and could be partially explained because Bobbo et al (2018) used a multiple trait linear model for a binary instead of a threshold model like the one used in this study.

A somatic cell count is a management tool and milk quality criterion which is incorporated in all milk recording schemes and can be used in genetic selection because of its association with both, clinical and subclinical mastitis (Sharma et al 2011). However, few studies have researched the genetic variability of alternative SCC traits. Nordic countries, where only veterinarians are allowed to treat animals, have nationwide systems for health data recording (Miglior et al 2017). In countries like Chile with no regulated systems in place for dairy cattle health recording and having a sound milk recording scheme, the use of alternative SCC traits can be used in genetic selection to increment mastitis resistance.

The results of this study are relevant since it is widely recognised that SCC is a trait economically important as an indicator for mastitis infection. In Chile, the first selection index for the Chilean dairy cattle, under pastoral systems, was developed (VEL; Valor Económico Lechero for its acronym in Spanish) (Lama and Vargas 2020). In this index, mammary health is one of the seven traits included. Since there are no previous studies on genetic parameters for mastitis resistance in the Chilean dairy cattle, our results can be used for simulation studies to predict genetic resistance to mastitis.

\section{ACKNOWLEDGEMENTS}

The authors would like to thank Dr. Ignacy Misztal, University of Georgia, USA, for permitting the use of the RENUMF90 and THRGIBBSF90 software.

\section{REFERENCES}

Bobbo T, Penasa M, Finocchiaro R, Visentin G, Cassandro M. 2018. Alternative somatic cell count traits exploitable in genetic selection for mastitis resistance in Italian Holsteins. J Dairy Sci 101, 10001-10010.

Bravo K. 2009. Estudio de incidencia y prevalencia de mastitis y su impacto económico en lecherías de la X región. 67 p. Undergraduate Dissertation, Universidad de Chile, Santiago, Chile.

Casella G, George EI. 1992. Explaining the Gibbs sampler. Amer Stat 46, 167-174.

Gianola D. Foulley JL. 1983. Sire evaluation for ordered categorical data with a threshold model. Genet Sel Evol 15, 201-224.

Gianola D, Sorensen D. 2002. Likelihood, Bayesian and MCMC methods in quantitative genetics. Springer-Verlag Inc., New York, USA.

Harville DA, Mee RW. 1984. A mixed model procedure for analyzing ordered categorical data. Biometrics 40, 303-408.

International Dairy Federation. 1997. Recommendations for presenting of mastitis related data. IDF Bulletin 321, Brussels, Belgium.

Kadarmideen HN, Thompson R, Simm G. 2000. Linear and threshold model genetic parameters for disease, fertility and milk production in dairy cattle. Anim Sci 71, 411-419.

Kirsanova E, Heringstad B, Lewandowska-Sabat A, Olsaker I. 2019. Alternative subclinical mastitis traits for genetic evaluation in dairy cattle. J Dairy Sci 102, 5323-5329.

Kumari T, Bhakat C, Choudhary RK. 2018. A review on sub clinical mastitis in dairy cattle. Int J Pure App Biosci 6, 1291-1299.

Lama J, Vargas P. 2020. Indice económico para la selección de bovinos lecheros en Chile. Cooprinforma 157, 18-21.

Lembeye F, López-Villalobos N, Burke JL, Davis S. 2016. Estimation of genetic parameters for milk traits in cows milked once- or twicedaily in New Zealand. Livest Sci 185, 142-147.

López-Villalobos N, Edwards JP, Jago JG. 2014. Estimation of genetic and crossbreeding parameters of milking characteristics of grazing dairy cows. New Zealand J Agric Res 57, 180-191.

Miglior F, Fleming A, Malchiodi F, Brito LF, Martin P, et al. 2017. A 100-year review: Identification and genetic selection of economically important traits in dairy cattle. J Dairy Sci 100, 10251-10271.

Misztal I. 2008. Reliable computing in estimation of variance components. J Anim Breed Genet 125, 363-370.

Montaldo HH, Castillo-Juárez H, Lizana C, Trejo C, Cienfuegos-Rivas $\mathrm{EG}$, et al. 2015. Genotype-environmental interaction between Chile and North America and between Chilean herd environmental categories for milk yield traits in Black and White cattle. Anim Sci Pap Rep 33, 23-33.

National Mastitis Council. 2013. Proceedings of the $52^{\text {nd }}$ Annual Meeting. NMC, San Diego, California.

Pinedo PJ, Meléndez P. 2010. Patrones temporales de recuento de células somáticas, grasa, proteína y nitrógeno ureico en leche de estanque y su asociación con fertilidad en ganado lechero en la zona centro-sur de Chile. Arch Med Vet 42, 41-48.

Ruegg PL, Pantoja JCF. 2013. Understanding and using somatic cell counts to improve milk quality. Irish J Agric Food Res 52, 101-117.

Sharma N, Singh NK, Bhadwal MS. 2011. Relationship of somatic cell count and mastitis: An Overview. Asian-Aust J Anim Sci 24, 429-438.

Sorensen DA, Andersen S, Gianola D, Korsgaard I. 1995. Bayesian inference in threshold models using Gibbs sampling. Genet Sel Evol 27, 229-249.

Uribe H, Kennedy BW, Martin SW, Kelton DF. 1995. Genetic parameters for common health disorders of Holstein cows. J Dairy Sci 78, 421-430.

Werner EG. 2014. Relación de la producción de leche y calidad sobre el recuento de células somáticas en rebaños del sur de Chile. Undergraduate Dissertation, Universidad Austral de Chile, Valdivia, Chile. 
